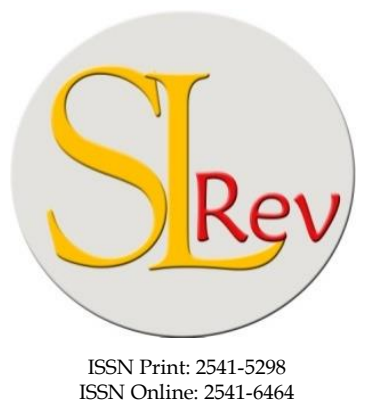

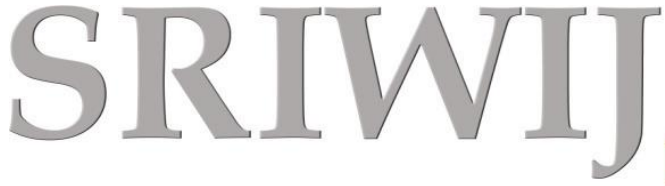
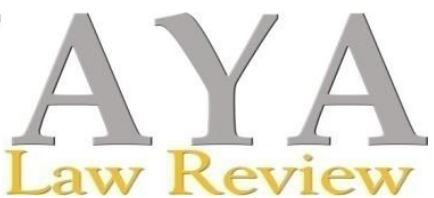

Editorial Office: Faculty of Law, Sriwijaya University

Jalan Srijaya Negara, Palembang, South Sumatra 30139, Indonesia.

Phone: +62711-580063Fax: +62711-581179

E-mail: sriwijayalawreview@unsri.ac.id| sriwijayalawreview@gmail.com

Website: http://journal.fh.unsri.ac.id/index.php/sriwijayalawreview

\title{
Freedom of Religion and Gender Equality in Sustainable Development Agenda
}

\author{
Khansadhia Afifah Wardana, ${ }^{\mathrm{a}^{*}}$ Rahayu, ${ }^{\mathrm{a}}$ and Sukirno ${ }^{\mathrm{a}}$
}

Faculty of Law, Universitas Diponegoro, Indonesia. Corresponding author Khansadhia Afifah Wardana, email: afifahkhansadhia@gmail.com

\begin{tabular}{ll}
\hline Article & Abstract \\
\hline Keywords: & $\begin{array}{l}\text { The implementation of Sustainable Development Goals (SDGs) often lacks in } \\
\text { human rights perspective, although the goals themselves were created based }\end{array}$ \\
$\begin{array}{l}\text { Freedom of religion; } \\
\text { Freedom of belief; Gen- } \\
\text { der equality; Human } \\
\text { rights; Sustainable De- } \\
\text { velopment. }\end{array}$ & $\begin{array}{l}\text { international human rights law show that it is essential to highlight that par- } \\
\text { ticular relationship. As a member of the international community, states have } \\
\text { an extraterritorial obligation to assist one another in developing and fulfilling } \\
\text { the human rights of their people. Particularly in the field of freedom of religion } \\
\text { or belief and gender equality, which creates a domino effect on other women's } \\
\text { rights such as access to justice and education. Although SDG 2030 has } \\
\text { expressed its commitment to respect, protect, and promote fundamental } \\
\text { freedoms, including one's religion, and to achieve gender equality, the } \\
\text { antagonistic construction between those two issues possibly harm the }\end{array}$ \\
$\begin{array}{l}\text { Article History } \\
\text { Received: Okt 25, 2021; } \\
\text { Reviewed: Jan 16, 2022; } \\
\text { Accepted: Jan 30, 2022; } \\
\text { Published: Jan 31,2022. } \\
\text { principle. The lack of recognition between those issues would be damaging } \\
\text { and could be deemed a failure to achieve the sustainable development goals. } \\
\text { This research was conducted through a qualitative legal analysis by analysing } \\
\text { 10.28946/slrev.Vol6.Iss1. }\end{array}$ \\
$\begin{array}{l}\text { relevant literary sources to understand the hidden link between freedom of } \\
\text { religion or belief and gender equality within the sustainable development } \\
\text { agenda. Clarity of these complex elements can be beneficial in creating a tool } \\
\text { in advocating for women's rights, especially for those who belong to religious } \\
\text { and belief minorities. }\end{array}$
\end{tabular}

(C)2022; This is an Open Access Research distributed under the term of the Creative Commons Attribution License (https://Creativecommons.org/licences/by/4.0), which permits unrestricted use, distribution, and reproduction in any medium, provided the original works is properly cited.

\section{INTRODUCTION}

The discourse on sustainable development started from a shared thought between the nations to create an ideal living environment for a human to live in. In 2015, Sustainable Development Goals, commonly known as SDGs, has given a new perspective that to establish the proper living environment, the development in question should focus on the environmental and economic aspects and other factors that have become an integral part of human lives. SDGs have core values of 
universalism, integration, and inclusivity that correspond with human rights values. No one should have been left behind in the development progress. Generally speaking, the strong relationship between human rights and SDGs should not be overlooked, starting from the right to a good and healthy environment, the right to education, children's rights, and other dependable human rights that latch on an individual.

The international human rights law has provided a premise for a liability mechanism that gives a chance for sustainable development in creating transformation and structural changes to eliminate inequality and power imbalances. ${ }^{1}$ International Covenant on Civil and Political Rights (ICCPR) and International Covenant on Economic and Social Rights (ICESCR) has given protection to several human rights notions that should be considered under the agenda of sustainable development. Included in the ICCPR is Article 18, which guarantees freedom of religion and belief without discrimination; encompassed within the article is a guarantee for the manifestation of religion or belief by its adherents with certain limitations. Fulfilling the right to freedom of religion and belief is often missed in discussions on sustainable development. Religious participation, which is becoming more central, has prompted special attention to include it in the fulfilment of the SDGs. Although, in practice, religion is often forgotten in the development process, critical thinking that connects the two elements originates from the thoughts of Western countries that adhere to secularism. ${ }^{2}$ In the last decade, academics and project officers have paid particular attention to the conceptual and methodological aspects between religion and development. ${ }^{3}$

The antagonistic construction between freedom of religion and belief with sustainable development produces negative consequences that override the importance of fulfilling freedom of religion or belief in the SDGs agenda, especially related to gender equality. Goal 5 of the SDGs mentioned "Achieving gender equality and empowering all women and girls", including women in religious groups or minority beliefs. These goals cannot be fulfilled unless sustainable development programs continue to encourage inclusiveness for all women without exception. The use of religious symbols, namely the niqab by women in public spaces, which is considered a crime in France, affects women's freedom to manifest their religion. The detention of Uighur Muslim women who are victims of rape and other violence is an example of discrimination and torture against women based on their beliefs.

However, actors advocating freedom of religion or belief and gender equality often avoid each other, assuming that the two have real differences and are impossible to reconcile. This thought stems from a narrow understanding that defines freedom of religion as a form of protection of 'religion', more precisely, a religion that is attached to patriarchal values. Negligence in leaving intersectionality, hence separating freedom of religion or belief and gender equality, has a negative impact on vulnerable groups who should have received legal protection. In addition, there are gaps in strategies or agendas to help those whose life situation is at the crossroads of discrimination

1 Markus Kaltenborn, Markus Krajewski, and Heike Kuhn, eds., Sustainable Development Goals and Human Rights, vol. 5, Interdisciplinary Studies in Human Rights (Cham: Springer International Publishing, 2020), 5, https://doi.org/10.1007/978-3-030-30469-0.

2 Emma Tomalin, "Thinking about Faith-Based Organisations in Development: Where Have We Got to and What Next?," Development in Practice 22, no. 5-6 (August 2012): 691, https://doi.org/10.1080/09614524.2012.686600.

3 Carole Rakodi, "A Framework for Analysing the Links between Religion and Development," Development in Practice 22, no. 5-6 (August 2012): 642, https://doi.org/10.1080/09614524.2012.685873. 
based on religion, belief and gender. ${ }^{4}$ Based on the explanation above, the objective of this article is to provide a concise and clear explanation of the relationship between international human rights law and Sustainable Development Goals (SDGs), especially on the aspect of Freedom of Religion and Belief in gender equality.

\section{RESEARCH METHOD}

This research was done through qualitative legal analysis, reflecting several international human rights instruments and the SDG agenda to recollect the missing narrative between gender equality and religious freedom. Data and information were collected through relevant literature sources, which aimed to identify the main issue regarding freedom of religion or belief and gender equality within the context of sustainable development agenda. Bibliographic sources include international human rights instruments, academic articles, and publications.

\section{ANALYSIS AND DISCUSSION}

\section{Sustainable Development Goals (SDGs) and International Human Rights Law}

Sustainable Development is a concept that came from a long process and debate between the need for development and awareness of the importance of environmental protection. In 1983, the United Nations General Assembly created an agency tasked with reviewing some of the critical issues related to the development and the environment, as well as formulating steps that are innovative, concrete and realistic to overcome these problems. This institution is called the World Commission on Environment and Development (WCED), also known as the Brundtland Commission. The commission defined sustainable development as a "development that meets the needs of the present without compromising the ability of future generations to meet their own needs". 5 Sands mentioned that the core elements of sustainable development that stemmed from international law are the integration principle, intergenerational equity, as well as the principle of sustainable use. ${ }^{6}$ In particular, the integration principle is pushing the development agenda to highlight the relation between SDGs and human rights, social, economic, as well as environmental objectives.

The relationship between development and human rights has long been contested, making it a central discussion in constructing a progressive development. ${ }^{7}$ However, until now, the dynamics of this relationship still cannot be fully explained. International human rights instruments are one of the main factors in providing the foundation and connecting the common thread between human rights and sustainable development. ${ }^{8}$ The concept of development as a human right was first officially recognised through the Vienna Declaration in 1993, including the right to development. This concept is a radical strategy for human rights to provide other legal principles in maintaining a

4 Nazila Ghanea, "Women and Religious Freedom," United States Commission on International Religious Freedom (2017).

5 Sharon Beder, Environmental Principles and Policies, 0 ed. (Routledge, 2013), 18, https://doi.org/10.4324/9781315065908.

6 Philippe Sands et al., Principles of International Environmental Law, 3rd ed (Cambridge ; New York: Cambridge University Press, 2012), 199.

7 Mac Darrow, "The Millennium Development Goals: Milestones or Millstones? Human Rights Priorities for the Post-2015 Development Agenda" 15 (2012): 60.

8 OECD and World Bank, Integrating Human Rights into Development, Second Edition: Donor Approaches, Experiences, and Challenges (The World Bank, 2013), 124, https://doi.org/10.1596/978-0-8213-9621-6. 
partnership within the international community, namely through international solidarity, equality, and substantive justice. ${ }^{9}$ The relation between those legal principles are closely linked with the outer dimension of the concept of the right to the development itself, namely international cooperation and assistance between one country and another within the international community is facing structural challenges inherent in the pursuit of prosperity. Several treaty bodies have emphasised that fulfilling human rights aspects, especially economic, social and cultural rights, children's rights, and the rights of people with disabilities, requires a strategic partnership between states. The United Nations Human Rights Committee stated as follows, "The international human rights legal framework, to which all States have subscribed, must be seen as part of the solution and the baseline commitment on development". ${ }^{10}$

Each state has an extraterritorial obligation that does not have the resources to fulfil these human rights to seek assistance from international actors. ${ }^{11}$ Assistance in the context of development based on international agreements and membership of international organisations actually has a human rights foundation. Statements from UN committees emphasised that both developing and developed countries have an obligation to collaborate in development. This is where the official development assistance (ODA) became an integral part of the whole process. The spotlight is on the states which posed a role as duty bearers to ensure and safeguard the human rights where the rights holders live. Discussions on sustainable development from a human rights approach have three unique characteristics that meet each other on one principle, namely 'inclusive development'.

First, international human rights law through the Universal Declaration of Human Rights (UDHR) has defined human rights as universal, inseparable, and inherent in every human being. However, at the same time, international human rights instruments recognise in the environmental and social settings are critical variables in a state's ability to fulfil and safeguard the human rights of its citizens. Lack of resources to ensure those rights is a legitimate claim to seek assistance from the international community. ${ }^{12}$ Second, human rights are interrelated and inseparable, implying that all human rights are equally significant. Hence, the realisation of one right (for example, the right to education) is significantly dependent on the fulfilment of other human rights (e.g. freedom of religion and belief without any discrimination to every student). This perspective is crucial for understanding the notion of development as a multi-dimensional phenomenon. As the 1986 Declaration of the Right to Development puts it, "an inalienable human rights by virtue of which every human person and all peoples are entitled to participate in, contribute to, and enjoy economic, social, cultural and political development."

9 Kaltenborn, Krajewski, and Kuhn, Sustainable Development Goals and Human Rights, 5:177.

10 United Nations, ed., Claiming the Millennium Development Goals: A Human Rights Approach (New York: United Nations, 2008).

11 Wouter Vandenhole, "Economic, Social and Cultural Rights in the CRC: Is There a Legal Obligation to Cooperate Internationally for Development?," The International Journal of Children's Rights 17, no. 1 (2009): 24, https://doi.org/10.1163/157181808X358267.

12 Elizabeth Stuart and Jessica Woodroffe, "Leaving No-One behind: Can the Sustainable Development Goals Succeed Where the Millennium Development Goals Lacked?," Gender \& Development 24, no. 1 (January 2, 2016): 75, https://doi.org/10.1080/13552074.2016.1142206. 
Finally, human rights can be viewed as both a substantive goal and a process that must adhere to non-discrimination, participation, and accountability criteria. These elements are actually the main characteristics of a sustainable development program and a strong foundation in the human rights law system, which is applicable both nationally and globally. The interaction and relationship between human rights and the Sustainable Development Goals highlighted the importance of the development process, which should not only focus on the aspect of finance or the economic environment. Many contributing factors in achieving sustainable development also include various aspects of human rights that are integral to an individual. Human rights law may be able to play a critical role in reframing the emerging concept of the labour division for sustainable development. It helps to reaffirm international cooperation in explicit and clarify the role of external actors and their duty in realising sustainable development.

Fukuda-Parr mentioned that the obstacles that may hinder international development policy in the context of human rights law were to "shift international cooperation from charity to solidarity" $^{13}$, this perspective has been a central topic within a political debate. Further discussion has also created two different sides in deciding whether it is a rigid legal obligation to provide international cooperation and assistance. Karimova introduced two different schools of thought on that matter. The first is maximalist, which refers to treaties elucidating international assistance and cooperation under the complex legal extraterritorial obligations. The second one is the minimalist, in which international cooperation in terms of providing aid was merely a means and measure, not an autonomous obligation. ${ }^{14}$ Nevertheless, extraterritorial obligations to fulfil human rights to create an international partnership for development should not be taken for granted. Development assistance is one of them from the overall spectrum of international partnership. The partnership entails a legal obligation in providing aid and assistance within the development agenda. In addition to the obligation to assist, all types of obligations may be relevant, for example, the duty to respect and protect human rights while assessing all policies with a critical impact. Other than that, the availability of resources to provide for other states lies within the margin of appreciation of each state. Resources may include financial, technology, or logistics.

The preamble of the 2030 SDGs shows that conceptually the agenda is based on human rights values, "17 Sustainable Development Goals and 169 targets seeks to realise human rights of all" this phrase shows that every goal of the SDGs agenda applies universally. However, statements that are not accompanied by adequate actions challenge realising human rights values in the SDGs agenda. States and other actors can overlook human rights in pursuing sustainable development goals due to ineffective oversight and accountability procedures. The idea of incorporating human rights into the sustainable development agenda is essentially wishful thinking without political will and significant support from civil society.

13 Sakiko Fukuda-Parr, "Millennium Development Goal 8: Indicators for International Human Rights Obligations?," Human Rights Quarterly 28, no. 4 (2006): 967, https://doi.org/10.1353/hrq.2006.0046.

14 Takhmina Karimova, "The Nature and Meaning of 'International Assistance and Cooperation' under the International Covenant on Economic, Social and Cultural Rights," in Economic, Social, and Cultural Rights in International Law (Oxford: Oxford University Press, 2014), 169-71, https://doi.org/10.1093/acprof:oso/9780199685974.003.0006. 


\section{Crucial Issues in Freedom of Religion and Belief, and Goal 5 (Gender Equality) of SDGs}

The instrument for protecting women's rights from discrimination or the Convention on Elimination of All Forms of Discrimination against Women (CEDAW) does not have a clause protecting freedom of religion and belief from discrimination. The movement and advocacy of women's rights have historically been closely linked to secularism, ignoring religion with the assumption that religion is the source of discriminatory practices and rituals that harm women, which should be avoided in women's rights advocacy. However, from a human rights perspective, Bielefeldt said that freedom of religion or belief is a norm that can be adopted by all groups ranging from liberal groups feminists to conservative and traditional groups in unravelling the complex relationship of religion and belief with other issues, including gender issues. ${ }^{15}$ Although actually in international human rights law, there is no consensus in understanding the definition of "religion" and "belief." But, General Comment Number 22 of the Committee on Civil and Political Rights explains that freedom of thought, belief and religion includes freedom of thought in all aspects, personal beliefs and commitments to that religion or belief, are not only religion and institutional beliefs but also customary beliefs and practices.

The role of women in the context of religion, according to Nazila Ghanea aims to provide opportunities for women to interpret religious verses to have a voice in interpreting sacred religious texts, which is included in the fulfilment of human rights. Discrimination and inequality based on religion and gender often occur together. Research from the Pew Research Center shows a strong correlation in countries with high restrictions on freedom of religion or belief and weak protections for gender equality. ${ }^{16}$ The challenges in drawing a red line between religion and gender are often met in discrimination on the basis of religion which has consequences for gender advocacy. Persecution of religious minorities can take the form of gender-based violence, namely, forced marriage, kidnapping, rape, and forced sterilisation. This depiction of reality demonstrates how religious freedom and gender equality abuses have a broad impact on other aspects of human rights. Economic and social rights violations, such as discrimination against the right to employment, the right to health, and the right to education on the basis of religion or belief, demonstrate the interdependence, interconnection, and indivisible nature of human rights.

Discriminatory practices that violate women's rights are complex and multi-layered phenomena based on religious motives and political, cultural, social, and historical aspects. When the state becomes the leading actor in the practice of religious discrimination, they often argue for reasons of state security and the desire to control their political power, as happened in the persecution of Uighur Muslim groups by the Chinese government. ${ }^{17}$ The absence of freedom of religion or belief protection for women also affects their right to opinion and expression. Women are not given the opportunity or are not even allowed to choose beliefs they desire and use as guidelines in their daily lives. So indirect freedom of religion and belief is one of the main tools for women to identify and synergise in advocating for women's rights. The confrontation between religion and gender

15 Elizabeta Kitanovic, Göran Gunner, and Pamela Slotte, eds., Human Rights, Religious Freedom and Faces of Faith, Globethics.Net CEC, no. 6 (Geneva: Globethics.net CEC, 2019), 41.

16 "Religion Holds Women Back. Or Does It?," World Economic Forum, accessed November 23, 2021, https://www.weforum.org/agenda/2015/11/religion-holds-women-back-or-does-it/.

17 Joanne Smith Finley, "Why Scholars and Activists Increasingly Fear an Uyghur Genocide in Xinjiang," Journal of Genocide Research 23, no. 3 (July 3, 2021): 2, https://doi.org/10.1080/14623528.2020.1848109. 
equality could be turned into a partnership so that the fulfilment of human rights in a holistic manner can be achieved.

Putting freedom of religion or belief and gender equality on the sustainable development agenda focuses on the principle of 'no one is left behind, including women in religious or belief minority groups and those who are often become the victims of discrimination on the basis of religion and gender. There is no discussion of religion in the SDGs goals except in Goal 10, which promotes inclusiveness of all age groups, sex, disability, race, ethnicity, origin, religion, economy, and status. The lack of attention and focus on religion and belief is considered a blind spot in efforts for sustainable development agenda and the fulfilment of human rights. Highlighting the relationship between freedom of religion or belief and gender equality can motivate the emergence of a broader and clearer analysis than the lens of law and human rights.

Talking about freedom of religion and belief cannot be separated from the main obstacle in fulfilling these rights, namely the existence of blasphemy laws, which are often posed as a tool to 'attack' religious groups and minority beliefs. Indonesia itself has Law No. 1/1965 concerning the Prevention, Abuse and Blasphemy of Religion or the Blasphemy Law. One of the victims was Meiliana, a Chinese woman who was sentenced to 18 months in prison by the Medan District Court for the complaints she made about azan calling in mosques. The Blasphemy Law in Indonesia was originally intended to stop the spread of atheism and beliefs that are considered deviant and pose a threat to the unity and integrity of Indonesia. ${ }^{18}$ The practice of blasphemy law, which tends to be arbitrary, also occurs in other countries. Another example is the case of Asia Bibi, a Catholic woman in Pakistan who was accused of insulting Islam. The blasphemy regulation is also considered a threat to the existence of traditional beliefs and religious teachings that do not follow the majority orthodoxy, making the position of religious groups and minority beliefs more vulnerable to persecution and discrimination.

The sustainable development agenda also prioritises creating access to education that is inclusive, fair and equal, without exception. Education, freedom of religion and belief, and gender equality are closely related because article 29 (1) of the Convention on the Rights of the Child states that education aims to "prepare children for responsible life in a free society, in the spirit of mutual understanding, peace, tolerance, equality of the sexes, and friendship between all nationalities, ethnicities, nationals and religious groups, and indigenous peoples." Fulfilling the right to equal education and inclusivity is the key to realising freedom of religion and belief and gender equality. All children have the right to be free from discrimination on the basis of religion and gender, including in the school environment. They also have the right to embrace religion, carry out religious manifestations and the right to be free from the coercion of religious instructions that are not in accordance with their beliefs.

In some cases, some laws prohibit certain religious groups from getting access to education, one of which is the Baha'i group in Iran, who are prohibited from continuing their education at public universities, thereby narrowing their opportunities in pursuing higher education. In addition, in terms of practice, some laws regulate religious clothing and symbols that students must wear

18 Aksel Tomte, “Constitutional Review of the Indonesian Blasphemy Law," Nordic Journal of Human Rights 30 (2012): 174 . 
when attending school. Problems arise when these regulations are implemented in public educational institutions that should not impose uniforms and symbols on the basis of religion. An example of this occurred in one of the public junior high schools in Yogyakarta when a female student was forced to wear a hijab by his teacher even when the school regulations did not oblige her to do so. Threats and acts of discrimination followed if the order was not obeyed. ${ }^{19}$ It is different from the existence of discriminatory regulations regarding uniforms, namely the French legislation, which does not allow students to wear head coverings or hijab and face-covering in public schools. ${ }^{20}$ The main challenge lies in school policies and discriminatory practices institutionalised in education management. Students belonging to religious groups or minority beliefs have a more vulnerable position than their friends who are included in the majority group. Threats, bullying, and physical punishment are very likely to occur. Suppose no education reform is able to use the perspective of human rights. In that case, education goals in the sustainable development agenda cannot be achieved perfectly.

Civil society and faith actors could play pivotal roles in breaking the ice when discussing freedom of religion or belief and gender equality. While both actors used different strategies and languages in interacting with the public, a concise plan and project could help bring this issue to the general public. Research has shown that throughout sustainable development goals, SDG 5 had become a controversial issue and "arousing divergent religious views" among faith actors. ${ }^{21}$ It does not mean a complete refusal by the faith actors to engage on this issue. However, it brings forward the sensitivity that encompassed the topic of religious dynamics. The process should also involve actors in traditional beliefs, proving that one of the challenges in promoting SDGs is the translation process that acknowledges the local context and the interrelatedness between religion and cultural norms without alienating the gender perspective.

The cases above illustrate the complex relationship in understanding freedom of religion and belief as well as gender equality, especially related to the sustainable development agenda. The principle of no one left behind is a foundation that must always be planted to improve situations that currently do not pay attention to women who are trapped between their religious identity and autonomy for themselves. Religion and belief can be a way of life and a medium in fighting for women's rights and not a 'trap' for women because of their closeness to patriarchal ideology. States cannot be said to be successful in achieving sustainable development goals when they choose to be ignorant in drawing a red line between freedom of religion or belief and gender equality.

\section{The Implement of the SDGs Related to Freedom of Religion and Gender Equality for the Parties}

The first step before going forward in creating a concrete project regarding freedom of religion and gender equality is to understand the universality of both rights, that religious freedom and

19 “'I Wanted to Run Away': Abusive Dress Codes for Women and Girls in Indonesia” (Human Rights Watch, March 18, 2021), https://www.hrw.org/report/2021/03/18/i-wanted-run-away/abusive-dress-codes-women-and-girlsindonesia.

20 Cassandra M Vogel, "An Unveiling: Exploring the Constitutionality of a Ban on Face Coverings in Public Schools," Brooklyn Law Review 78 (2012): 749.

21 Felix Dodds, Ambassador David Donoghue, and Jimena Leiva Roesch, Negotiating the Sustainable Development Goals: A Transformational Agenda for an Insecure World (London: Routledge, 2016), 38, https://doi.org/10.4324/9781315527093. 
gender equality are indivisible and interrelated, etched to each individual. It is crucial to read both rights in a holistic human rights approach, not as separate entities. The principle of nondiscrimination served as the basic foundation that no one should ever be discriminated against under the basis of sex and/or religion or belief. In the context of SDGs, the state as the primary duty bearer should be held accountable for the emergence of regulations that harm women's religious freedom, as pointed above in some cases. The second one is to do a reassessment to domestic policies and laws should be a priority for the state to find a blind spot in recognising discrimination on the basis of gender and/or religion, as well as finding a proper guideline in reforming those laws from international human rights instruments and other regional human rights bodies. Establishing clarity and systemic legal protection, particularly for religious freedom and gender equality, would be vital progress in these circumstances. The process of legal reform should have taken input from various key actors, one of which is the person who has lived the experience, facing discrimination on the basis of their gender identity and religion or belief. The failure to create an alliance and understand the victim's hardship would put the newly established regulation to waste.

Grassroot organisations and local religious leaders should have been able to work together, facilitated by the state, in opening a safe space for a dialogue to happen. It is focused on revitalising the relationship between freedom of religion or belief and gender equality in every aspect, such as health and education. The main challenge in this partnership is to break the barrier in mostly maledominated and patriarchal religious groups that often shun women's roles and authority within a religious community. One example of a monumental breakthrough in response to this challenge is the emergence of the Indonesian Women's Ulama Movement (KUPI) back in 2017, which often talks about the role of the female ulama in socio-political and cultural life within the country. In the light of the rising number of sexual violence cases in Indonesia, KUPI often advocates and campaign toward the legalisation of the anti-sexual violence bill, also giving their support toward the recent ministerial decree on prevention of sexual violence. KUPI has given a fine example in showcasing the role of religious actors engaging in the issue of religious freedom and gender equality. However, it is crucial to acknowledge that this kind of cooperation or strategic partnership should be able to reach all religious and belief communities, not just towards institutional religions such as Islam and Christian, but also those who adhere to lived religions or indigenous beliefs.

The complexity surrounding these issues makes it hard to create a comprehensive framework briefly. Small steps could have been undertaken in untangling the relationship between freedom of religion or belief and gender equality in the education and health department. The educational system could benefit in taking inspiration from school curricula proposed by UNESCO, namely the "Toolkit on revision of curricula, school textbooks, and other learning materials to remove cultural, religious and gender-biased stereotypes", to create materials that would eliminate religious and gender stereotypes. The SDGs 2030 aims to create an inclusive learning environment, leaving behind all forms of discrimination and inequalities towards students and focusing on human rights cultures instead. In the health department, religious values and norms significantly dampened safe dialogue on sexual and reproductive health, leading to misconceptions and endangering women's health. The notion of freedom of religion or belief could be the core point 
in efforts and progress in dismantling religious prejudice and hostility toward sexual and reproductive health issues. The objective is to decrease women's suffering and improve their wellbeing. Raising awareness and recognising the struggling relationship between freedom of religion or belief and women's equality could be a potential tool in addressing core issues of discrimination and disempowerment. If these intersectional issues could be appropriately addressed, the SDGs 2030 agenda could be achieved inclusively.

\section{CONCLUSION}

The sustainable development agenda closely relates to aspects of international human rights law. The human rights perspective, which is based on equality and non-discrimination, is an essential foundation in realising the agenda of Sustainable Development Goals. Human rights' interdependent and inseparable nature provides an impetus for every state not to ignore human rights values in its development process. The correlation between freedom of religion and gender equality within the agenda of sustainable development is often not a significant issue in the struggle for women's rights. Clarification of the relationship between these complex elements can be a tool to help advocate the rights of women, especially those from religious groups or minority beliefs. Further action is needed after understanding the relationship between freedom of religion and gender equality in the SDGs, and implementation must be done through concrete policies and related programs for the realisation of sustainable development without leaving anyone behind.

\section{REFERENCES}

Beder, Sharon. Environmental Principles and Policies. 0 ed. Routledge, 2013. https://doi.org/10.4324/9781315065908.

Darrow, Mac. "The Millennium Development Goals: Milestones or Millstones? Human Rights Priorities for the Post-2015 Development Agenda" 15 (2012): 74.

Dodds, Felix, Ambassador David Donoghue, and Jimena Leiva Roesch. Negotiating the Sustainable Development Goals: A Transformational Agenda for an Insecure World. London: Routledge, 2016. https://doi.org/10.4324/9781315527093.

Fukuda-Parr, Sakiko. "Millennium Development Goal 8: Indicators for International Human Rights Obligations?" Human Rights Quarterly 28, no. 4 (2006): 966-97. https://doi.org/10.1353/hrq.2006.0046.

Ghanea, Nazila. "Women and Religious Freedom," United States Commission on International Religious Freedom, 2017.

“"I Wanted to Run Away': Abusive Dress Codes for Women and Girls in Indonesia." Human Rights Watch, March 18, 2021. https://www.hrw.org/report/2021/03/18/i-wanted-runaway/abusive-dress-codes-women-and-girls-indonesia.

Kaltenborn, Markus, Markus Krajewski, and Heike Kuhn, eds. Sustainable Development Goals and Human Rights. Vol. 5. Interdisciplinary Studies in Human Rights. Cham: Springer International Publishing, 2020. https://doi.org/10.1007/978-3-030-30469-0.

Karimova, Takhmina. "The Nature and Meaning of 'International Assistance and Cooperation' under the International Covenant on Economic, Social and Cultural Rights." In Economic, 
Social, and Cultural Rights in International Law. Oxford: Oxford University Press, 2014. https://doi.org/10.1093/acprof:oso/9780199685974.003.0006.

Kitanovic, Elizabeta, Göran Gunner, and Pamela Slotte, eds. Human Rights, Religious Freedom and Faces of Faith. Globethics.Net CEC, no. 6. Geneva: Globethics.net CEC, 2019.

OECD and World Bank. Integrating Human Rights into Development, Second Edition: Donor Approaches, Experiences, and Challenges. The World Bank, 2013. https://doi.org/10.1596/978-0-8213-9621-6.

Rakodi, Carole. "A Framework for Analysing the Links between Religion and Development." Development in Practice 22, no. 5-6 (August 2012): 634-50. https://doi.org/10.1080/09614524.2012.685873.

World Economic Forum. "Religion Holds Women Back. Or Does It?" Accessed November 23, 2021. https://www.weforum.org/agenda/2015/11/religion-holds-women-back-or-does-it/.

Sands, Philippe, Jacqueline Peel, Adriana Fabra Aguilar, and Ruth MacKenzie. Principles of International Environmental Law. 3rd ed. Cambridge ; New York: Cambridge University Press, 2012.

Smith Finley, Joanne. "Why Scholars and Activists Increasingly Fear a Uyghur Genocide in Xinjiang." Journal of Genocide Research 23, no. 3 (July 3, 2021): 348-70. https://doi.org/10.1080/14623528.2020.1848109.

Stuart, Elizabeth, and Jessica Woodroffe. "Leaving No-One behind: Can the Sustainable Development Goals Succeed Where the Millennium Development Goals Lacked?" Gender \& Development 24, no. 1 (January 2, 2016): 69-81. https://doi.org/10.1080/13552074.2016.1142206.

Tomalin, Emma. "Thinking about Faith-Based Organisations in Development: Where Have We Got to and What Next?" Development in Practice 22, no. 5-6 (August 2012): 689-703. https://doi.org/10.1080/09614524.2012.686600.

Tomte, Aksel. "Constitutional Review of the Indonesian Blasphemy Law," Nordic Journal of Human Rights 30 (2012):174.

United Nations, ed. Claiming the Millennium Development Goals: A Human Rights Approach. New York: United Nations, 2008.

Vandenhole, Wouter. "Economic, Social and Cultural Rights in the CRC: Is There a Legal Obligation to Cooperate Internationally for Development?" The International Journal of Children's Rights 17, no. 1 (2009): 23-63. https://doi.org/10.1163/157181808X358267.

Vogel, Cassandra M. "An Unveiling: Exploring the Constitutionality of a Ban on Face Coverings in Public Schools.” Brooklyn Law Review 78 (2012): 37. 